УДК 342.25

Недопад Г.В., аспірант

Луцький національний технічний університет

Nedopad H., graduate student, Department of Finance, Banking and Insurance https://orcid.org/0000-0002-7692-861X

\title{
ОСОБЛИВОСТІ ОЦІНКИ БЮДЖЕТНОЇ ЕФЕКТИВНОСТІ ОТГ ВОЛИНСЬКОЇ ОБЛАСТІ
}

\author{
Луцький національний технічний університет
}

\begin{abstract}
У статті розкрито передумови вдосконалення системи аналізу бюджетної ефективності місцевих бюджетів. На основі аналізу наукових підходів розроблено методичні положення комплексного аналізу бюджетної ефективності місцевих бюджетів, що передбачають розрахунок інтегрального показника за блоками бюджетної результативності, бюджетної самодостатності та бюджетної відкритості. Наведено результати апробації запропонованого підходу до аналізу на прикладі бюджетів об'єднаних територіальних громад Волинської області.

Дослідження бюджетної результативності грунтуватиметься на оцінці рівня виконання видатків місцевих бюджетів ОТГ за функціональною класифікацією.

Загальновідомим є факт, що самодостатні територіальні громади $€$ основою місцевого i регіонального розвитку будь-якої держави. Це також є ознакою ефективності місцевого самоврядування. До індикаторів, що визначатимуть бюджетну самодостатність нами віднесено: доходи загального фонду на 1-ного мешканця, питому вагу управлінських витрат у власних доходах, капітальні видатки на 1-ну особу, рівень дотаційності бюджетів ОТГ Волинської області, видатки загального фонду на одного мешканця, питому вага капітальних видатків у загальній сумі видатків, питому вагу ЗП з нарахуваннями у видатках загального фонду, видатки на утримання апарату управління на 1-го мешканця, обсяг надходжень до бюджету ОТГ від сплати ПДФО на 1-го мешканця, обсяг надходжень до бюджету ОТГ від плати за землю на 1-го мешканця, обсяг надходжень до бюджету ОТГ від сплати єдиного податку на 1-го мешканця, обсяг надходжень до бюджету ОТГ від сплати акцизного податку на 1-го мешканця, обсяг надходжень до бюджету ОТГ від сплати податку на нерухоме майно на 1-го мешканця.

Аналіз рівня інформаційної відкритості органів управління ОТГ проведено на основі дослідження фіційних сайтів об'єднаних громад Волинської області та визначено його вплив на формування бюджетної ефективності території. За допомогою офіційних сайтів об'єднаних громад промоніторено взаємозв'язок між представленим на ньому контентом та бюджетною ефективністю окремо взятої ОТГ.
\end{abstract}

Ключові слова: адміністративно-територіальна реформа, бюджетна ефективність, децентралізачія, місиеві бюджети, об'єднані територіальні громади.

\section{FEATURES OF BUDGET EFFICIENCY EVALUATION UTC OF VOLYN REGION}

\section{Lutsk National Technical University}

The article reveals the prerequisites for improving the system of analysis of budget efficiency of local budgets. Based on the analysis of scientific approaches, methodological provisions for a comprehensive analysis of the budget efficiency of local budgets have been developed, which provide for the calculation of an integrated indicator for the blocks of budget performance, budget self-sufficiency and budget openness. The results of approbation of the proposed approach to the analysis on the example of the budgets of the united territorial communities of Volyn region are given.

The study of budget performance will be based on the assessment of the level of execution of UTC local budget expenditures by functional classification.

It is a well-known fact that self-sufficient territorial communities are the basis of local and regional development of any state. It is also a sign of the effectiveness of local self-government.

The indicators that will determine the budget self-sufficiency we include: revenues of the general fund per 1 inhabitant, the share of management costs in own revenues, capital expenditures per 1 person, the level of subsidies of UTC budgets of Volyn region, general fund expenditures per capita, specific the weight of capital expenditures in the total amount of expenditures, the share of salary with accruals in the expenditures of the general fund, expenditures for the maintenance of the management staff per 1 inhabitant, volume of receipts to the budget of UTC from payment of the personal income tax on 1 inhabitant, volume of receipts to the budget of UTC from payment for the earth on 1 inhabitant, volume of receipts to the budget of UTC from payment of the uniform tax 
on 1 inhabitant, volume of receipts to the budget of UTC from payment of excise tax per 1 inhabitant, the amount of revenues to the budget of UTC from the payment of real estate tax per 1 inhabitant.

The analysis of the level of information openness of UTC management bodies was carried out on the example of official websites of the united communities of Volyn region and its influence on the formation of budget efficiency of the territory was determined. With the help of the official websites of the united communities, the relationship between the content presented on it and the budget efficiency of the individual UTC was monitored.

Key words: administrative-territorial reform, budget efficiency, decentralization, local budgets, united territorial communities.

Постановка проблеми у загальному вигляді i iï зв'язок 3 важливими науковими та практичними завданнями. Збалансований розподіл місцевих бюджетів, якій є запорукою фінансової стабільності країни, потребує налагодженого механізму управління бюджетом, яка змогла б забезпечити ефективне накопичення та використання коштів. Адже ефективність розподілу фінансових ресурсів через місцеві бюджети впливає на соціально-економічний розвиток територій, а це стає можливим при наявності дієвої бюджетної політики.

Аналіз останніх досліджень, у яких започатковано вирішення проблеми. Дослідженням ефективності використання бюджетних коштів присвячено праці таких вітчизняних учених, як В. Горин, В. Дем'янишин, Б. Заблоцький, Б. Карпінській, О. Кириленко, Б. Малиняк, Г. Маркович та ін. Віддаючи належне високому рівню наукових робіт, зазначимо, що недостатньо уваги все ж приділяється розробці науково обгрунтованих методик оцінки бюджетної ефективності місцевих бюджетів.

Цілі статті - дослідити та обгрунтувати методичні підходи до оцінювання бюджетної ефективності об'єднаних територіальних громад Волині.

Виклад основного матеріалу дослідження 3 повним обгрунтуванням отриманих наукових результатів.

Результативність органів місцевого самоврядування залежить насамперед від їхніх фінансових можливостей, тобто здатності самостійно, за рахунок власних ресурсів, вирішувати питання регіонального значення. Нині ключовими викликами для об'єднаних територіальних громад є зміцнення доходної частини власних бюджетів, посилення соціальної направленості видатків бюджету та створення умов економічної стабілізації території.

Надати об'єктивну оцінку бюджетній ефективності можна за умови використання відповідної сукупності критеріїв та показників. На сьогоднішній час існує низка науковометодичних підходів і методів оцінювання, кожен із них має свої сильні і слабкі моменти, виражені в точності й трудомісткості вимірювання. На нашу думку, бюджетну ефективність доцільно визначати на основі 3 груп показників, які будуть зведені у групові індекси: індекс бюджетної результативності, індекс бюджетної самодостатності, індекс бюджетної транспарентності. Для забезпечення порівнянності між різними за кількістю населення, площею території чи іншими характеристиками регіонами відповідні за змістом показники представляються у розрахунку на певну кількість населення, відсотках, коефіцієнтах тощо. Статистична база первинних показників бюджетної ефективності об'єднаних територіальних громад (ОТГ) Волині сформована 3 офіційних джерел: державної служби статистики України, департаменту фінансів Волинської облдержадміністрації, інформаційного порталу «Децентралізація», офіційних сторінок ОТГ та ін. Часткові показники стимулятори/дестимулятори, які визначають бюджетну ефективність ОТГ Волинської області дозволили розрахувати відповідний таксономічний індекс, який буде покладений в основу діагностики присутності конвергентно-дивергентних процесів в регіоні. Система показників бюджетної ефективності об’єднаних територіальних громад представлена на рис. 1.

Перший блок показників (табл. 1) включає індикатори котрі визначають рівень виконання видаткової частини бюджетів ОТГ. 
Рівень виконання видатків місцевих бюджетів передбачає формування адекватної системи оціночних показників, здатних об'єктивно відобразити динаміку запланованих та отриманих результатів. Згадані індикатори орієнтуються на кінцеві суспільно-значимі результати (показники досягнутих результатів).

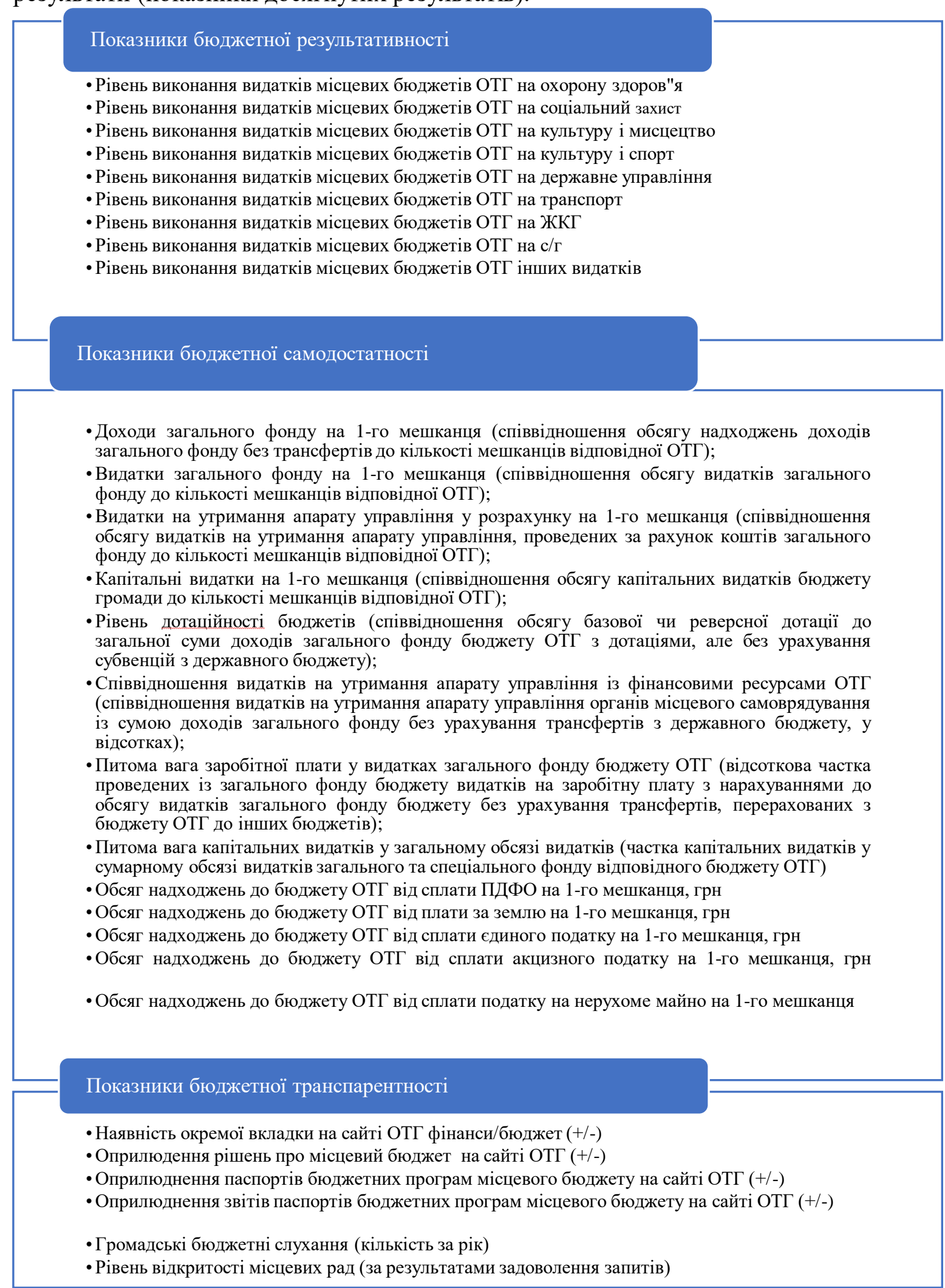

Рис. 1. Система показників бюджетної ефективності об’єднаних територіальних громад 
Таблиця 1

Показники бюджетної результативності ОТГ Волинської області у 2019 році

\begin{tabular}{|c|c|c|c|c|c|c|c|c|c|c|}
\hline \multirow[b]{2}{*}{ ОТГ Волинської області } & \multicolumn{10}{|c|}{ Рівень виконання видатків місцевих бюджетів ОТГ } \\
\hline & Освіта & Охорона здоров'я & Соціальний захист & Культура імистецтво & $\begin{array}{c}\text { Фізична культура i } \\
\text { спорт }\end{array}$ & $\begin{array}{r}\text { Державне } \\
\text { управління }\end{array}$ & Транспорт & $\begin{array}{l}\text { Житлово-комунальне } \\
\text { господарство }\end{array}$ & Сільське господарство & Інші видатки \\
\hline & & & & Група 1. ОТГ з чисельн & о населення більше 15 т & осіб & & & & \\
\hline Ківерцівська & 98,35 & 100,00 & 86,21 & 99,98 & 99,93 & 99,62 & 96,60 & 87,70 & 50,64 & 45,45 \\
\hline Любомльська & 90,74 & 100,00 & 99,69 & 99,38 & 99,13 & 99,50 & 95,58 & 98,87 & 100,00 & 99,96 \\
\hline Любешівська & 96,85 & 99,55 & 99,93 & 99,73 & 99,90 & 99,79 & 99,11 & 98,46 & 93,91 & 80,94 \\
\hline & & & & Група 2. ОТГ з чисельні & населення від 10 до 15 & c. ociб & & & & \\
\hline Підгаєтьська & 83,02 & 99,90 & 99,55 & 91,03 & 99,09 & 98,91 & 99,98 & 99,66 & 98,61 & 7,69 \\
\hline Колківська & 96,85 & & 97,59 & 96,90 & 68,81 & 99,45 & 99,55 & 90,99 & 99,53 & 94,56 \\
\hline Цуманська & 94,60 & & 93,32 & 94,01 & 75,71 & 99,17 & 98,19 & 93,17 & 45,96 & 93,86 \\
\hline Старовижівська & 94,39 & & 76,55 & 93,67 & 59,67 & & 92,54 & 87,11 & & 8,83 \\
\hline Забродівська & 91,99 & 98,43 & 97,96 & 97,29 & 84,97 & 98,65 & & 95,32 & 90,45 & 93,76 \\
\hline 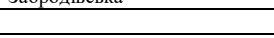 & 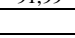 & 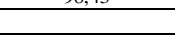 & 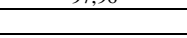 & Група 3. ОТГ з чисельні & населення від 5 до $10 \mathrm{~T}$ & c. ociб & & & (1) & (1) \\
\hline Боратинська & 87,18 & 93,06 & 85,67 & 88,17 & 90,28 & 96,10 & 87,86 & 97,92 & 25,67 & 93,74 \\
\hline Липинська & 79,63 & 99,95 & 75,63 & 87,99 & 61,15 & 98,57 & 99,97 & 97,51 & & 69,88 \\
\hline Княгининівська & 89,77 & 92,44 & 92,25 & 92,44 & & 88,21 & 99,99 & 90,20 & 82,72 & 63,80 \\
\hline Рівненська & 90,65 & 92,77 & 97,60 & 88,87 & 91,32 & 98,91 & 96,69 & 60,51 & 78,09 & 76,28 \\
\hline Заборольська & 86,43 & 94,12 & 91,04 & 88,89 & 77,57 & 96,81 & 93,80 & 89,61 & 54,25 & 61,28 \\
\hline Торчинська & 90,34 & & 90,80 & 76,76 & 79,04 & 92,50 & 97,11 & 84,53 & 97,27 & $\begin{array}{ll}61,06 \\
61,06\end{array}$ \\
\hline Вишнівська & 93,46 & 87,68 & 98,69 & 99,66 & 95,40 & 99,51 & 99,74 & 98,95 & 99,92 & 76,59 \\
\hline Устилузька & 91,98 & 48,72 & 85,49 & 83,11 & 67,32 & 94,39 & 46,98 & 75,56 & 39,04 & 69,71 \\
\hline Поромівська & 93,60 & & 87,21 & 74,53 & 51,52 & 98,04 & 76,58 & 96,48 & & 89,74 \\
\hline Прилісненська & 89,62 & 100,00 & 97,25 & 96,21 & 97,12 & 99,19 & 100,00 & 99,91 & 96,17 & 99,91 \\
\hline Турійська & 96,84 & & 99,88 & 93,00 & 96,08 & 99,13 & 90,56 & 94,74 & 99,80 & 46,63 \\
\hline Шацька & 96,34 & & 97,90 & 96,89 & 95,19 & 97,98 & 63,06 & 99,33 & 94,46 & 81,74 \\
\hline Іваничівська & 95,78 & & 99,17 & 88,66 & 98,93 & 99,01 & 97,99 & 99,41 & 98,83 & 81,49 \\
\hline Заболоттівська & 89,88 & 99,39 & 99,33 & 85,67 & 95,61 & 99,53 & 99,22 & 96,72 & 97,96 & 92,10 \\
\hline Зимнівська & 92,61 & 48,27 & 97,88 & 98,44 & 99,47 & 99,27 & 89,69 & 91,96 & 82,10 & 62,82 \\
\hline Самарівська & 85,21 & 90,20 & 83,99 & 92,75 & 66,40 & 98,63 & 99,90 & 76,65 & 93,62 & 62,61 \\
\hline Люблинецька & 99,34 & & 99,96 & 99,91 & 99,19 & 99,98 & 99,99 & 99,56 & 93,81 & 100,00 \\
\hline Гіркополонківська & 85,25 & 98,92 & 97,46 & 94,57 & 100,00 & 97,93 & 45,23 & 96,09 & 89,00 & 77,85 \\
\hline Гуто-Боровенська & 91,68 & 42,18 & 87,86 & 86,24 & 0,00 & 93,45 & 90,36 & 89,03 & 87,16 & 70,83 \\
\hline Затурцівська & 97,86 & 100,00 & 99,75 & 96,70 & 99,54 & 99,79 & 99,96 & 94,81 & 97,66 & 99,21 \\
\hline Копачівська & 99,25 & & 96,51 & 98,59 & 100,00 & 99,04 & 98,71 & 99,41 & 100,00 & 91,18 \\
\hline Голобська & 93,52 & & 98,15 & 94,92 & 97,29 & 97,85 & 77,04 & 95,87 & 67,52 & 85,16 \\
\hline Головненська & 93,94 & 100,00 & 86,18 & 96,71 & 88,42 & 98,26 & 99,87 & 91,25 & 96,64 & 90,06 \\
\hline 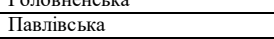 & $\frac{95,34}{96,31}$ & 100,00 & $\begin{array}{l}80,16 \\
98,50\end{array}$ & 90,011 & $\begin{array}{l}90,424 \\
99,97\end{array}$ & $\begin{array}{l}90,200 \\
98,77\end{array}$ & $\begin{array}{l}99,01 \\
99,71 \\
\end{array}$ & $\begin{array}{l}91,25 \\
99,74\end{array}$ & $\frac{10,04}{100,00}$ & $\begin{array}{l}90,506 \\
66,56\end{array}$ \\
\hline Дубечненська & 98,54 & 91,10 & 98,93 & 96,19 & 99,00 & 97,31 & 99,86 & 88,79 & 99,83 & 97,94 \\
\hline & & & & Група 4. ОТГ з чисел & стю населення до 5 тис. & & & & & \\
\hline Зарічанська & 93,80 & 97,63 & 90,31 & 94,70 & 76,39 & 85,90 & 93,24 & 89,42 & 32,66 & 20,37 \\
\hline Жидичинська & 84,68 & & 98,71 & 98,15 & 100,00 & 99,31 & 99,95 & 95,87 & 99,91 & 0,00 \\
\hline Городищенська & 92,96 & 100,00 & 97,05 & 92,51 & 84,56 & 96,88 & 76,14 & 94,55 & 98,03 & 0,00 \\
\hline Луківська & 98,70 & & 88,39 & 87,81 & 80,10 & 90,52 & 98,98 & 99,88 & 89,60 & 84,80 \\
\hline Дубівська & 87,90 & & 87,22 & 97,47 & 89,02 & 99,52 & & 98,77 & 99,77 & 92,49 \\
\hline Смолигівська & 97,48 & 99,99 & $\begin{array}{l}99,67 \\
99,67\end{array}$ & 97,07 & & 98,86 & 38,04 & 97,76 & 8,48 & 47,73 \\
\hline Литовезька & 91,86 & & 96,72 & 94,45 & 95,23 & 99,47 & 100,00 & 97,28 & 100,00 & \\
\hline Оваднівська & 98,46 & 99,55 & 95,53 & 97,76 & 98,07 & 98,51 & 99,29 & 98,10 & 97,88 & 97,91 \\
\hline Колодяжненська & 92,75 & & 97,63 & 99,45 & 73,20 & 98,04 & 99,28 & 95,81 & 90,93 & 88,42 \\
\hline Тростянецька & & & 99,96 & 96,11 & 93,95 & 95,62 & 96,43 & 95,01 & & \\
\hline Смідинська & 82,75 & 98,62 & 75,40 & 99,08 & 0,00 & 99,83 & 99,99 & 99,85 & 80,70 & 93,24 \\
\hline Привітненська & 86,87 & & 100,00 & 95,72 & & 97,52 & 94,68 & 65,61 & & 81,70 \\
\hline Поворська & 92,79 & & 98,14 & 96,93 & 99,28 & 96,67 & 100,00 & 96,54 & 99,74 & 8908 \\
\hline Велимченська & 84,58 & 88,66 & 99,80 & 99,09 & 99,80 & 99,39 & & 95,69 & 100,00 & 96,98 \\
\hline Сериховичівська & 95,48 & 95,78 & 95,77 & 95,67 & 0,00 & 97,65 & 89,53 & 87,02 & 99,24 & 78,37 \\
\hline Війницька & 98,37 & & 98,80 & 98,85 & 100,00 & 98,77 & 89,28 & 88,06 & 100,00 & 99,97 \\
\hline Велицька & 92,05 & & 93,95 & 90,75 & 5,07 & 97,76 & 18,91 & 82,38 & 61,70 & 80,07 \\
\hline Всього по ОТГ Волинської & 9269 & 9771 & 9678 & 9376 & $93233>23$ & 9744 & 9261 & 94,58 & 8012 & 8258 \\
\hline
\end{tabular}


До них віднесено рівень виконання видатків місцевих бюджетів ОТГ на освіту, рівень виконання видатків місцевих бюджетів ОТГ на охорону здоров'я, рівень виконання видатків місцевих бюджетів ОТГ на соціальний захист, рівень виконання видатків місцевих бюджетів ОТГ на культуру і мисцецтво, рівень виконання видатків місцевих бюджетів ОТГ на культуру і спорт, рівень виконання видатків місцевих бюджетів ОТГ на державне управління, рівень виконання видатків місцевих бюджетів ОТГ на транспорт, рівень виконання видатків місцевих бюджетів ОТГ на ЖКГ, рівень виконання видатків місцевих бюджетів ОТГ на с/г, рівень виконання видатків місцевих бюджетів ОТГ інших видатків.

Наголосимо на тому, що нині процес створення ОТГ перебуває в активній фазі та поки не завершений, а їхня чисельність варіюється щороку, тому вважаємо, що проведення аналізу показників бюджетної ефективності ОТГ у динаміці не має значимості. Зауважимо, що зростання кількості об'єднаних громад кожного року впливає на адекватність аналізу характеристик динаміки та унеможливлює його проведення для всіх громад, сформованих на певний момент часу, продукуючи недостовірність оцінки досліджуваних показників, а також втраті суті отриманих в такий спосіб оцінок.

Досліджені тенденції щодо виконання видатків за загальними та спеціальними фондами бюджетів ОТГ Волинської області свідчать про виконання взятих на себе зобов'язань органами місцевого самоврядування таких громад, як Затурцівська, Любомльська, Оваднівська, Прилісненська, Любешівська, Дубечненська, Заболоттівська, Вишнівська та Головненська. Проте в Старовижівській, Велицькій, Привітненській, Тростянецькій ОТГ визначені тенденції вказують на неефективність планування показників видатків бюджетів цих громад. Неефективність використання видатків $є$ однією з причин додаткового навантаження на бюджети ОТГ та зростання внутрішніх і зовнішніх загроз. Теоретично кожна громада має на меті використовувати свої ресурси максимально ефективно, проте на практиці досягти цього досить складно. Усі учасники бюджетного процесу мають усвідомлювати пріоритетність інтелектуальних зусиль при обмеженості бюджетних ресурсів у підвищенні рівня продуктивності використання бюджетних коштів на пріоритетні напрями розвитку громад. За висловлюванням Г. Саймона, у широкому розумінні “діяти ефективно” означає використовувати найкоротший спосіб і “найдешевші” засоби для досягнення бажаних цілей [1, с.12].

Основні причини недовиконання місцевих бюджетів за видатками систематизовані на рис. 2.

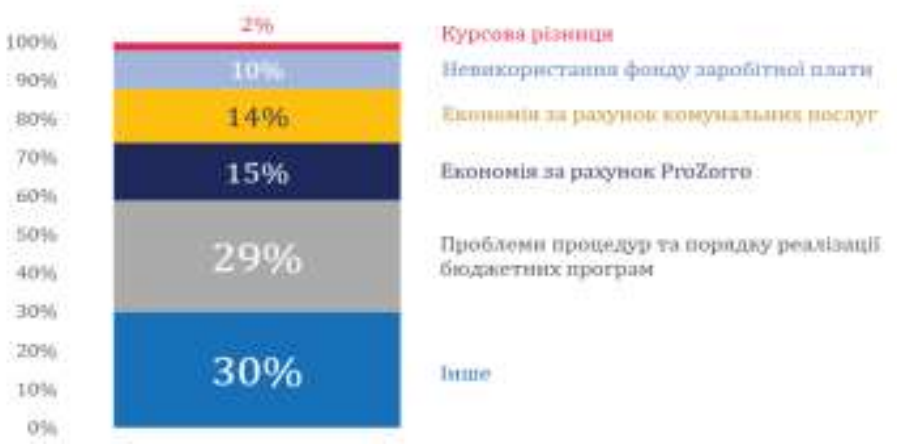

Рис. 2. Розподіл основних причин невиконання бюджетних програм відповідно до пояснень розпорядників коштів, \% [2]

Невиконання бюджетних програм відповідно до пояснюючих записок розпорядників коштів різних рівнів виникає у наслідок правових, організаційних та економічних змін до умов діяльності та функціонування розпорядників бюджетних коштів. «Зокрема, у цих бюджетних програмах спостерігається невикористання фонду 
заробітної плати, неповна сплата $\mathrm{CCB}$, недотримання структури та обсягів витрат у межах програми, скорочення витрат нажитлово-комунальні послуги, оптимізація бюджетних витрат на бюджетних закупівлях, недоотримання коштів за бюджетними асигнуваннями, скасування тендерів, невиконання договірних умов. Інші причини стосуються процедур реалізації бюджетних програм та пов'язаних з ними проблем, зокрема: невиконання умов договору, затримання строків будівництва, несвоєчасне укладання угод, скасування торгів, несвоєчасне надання науково-технічної документації, несхвалення програми на проведення дочасних виборів та інше» [2].

Наступний блок показників, які формують індекс бюджетної самодостатності та підлягають дослідженню сформований 3 наступних індикаторів: доходи загального фонду на 1-го мешканця (співвідношення обсягу надходжень доходів загального фонду без трансфертів до кількості мешканців відповідної ОТГ); видатки загального фонду на 1-го мешканця (співвідношення обсягу видатків загального фонду до кількості мешканців відповідної ОТГ); видатки на утримання апарату управління у розрахунку на 1-го мешканця (співвідношення обсягу видатків на утримання апарату управління, проведених за рахунок коштів загального фонду до кількості мешканців відповідної ОТГ); капітальні видатки на 1-го мешканця (співвідношення обсягу капітальних видатків бюджету громади до кількості мешканців відповідної ОТГ); рівень дотаційності бюджетів (співвідношення обсягу базової чи реверсної дотації до загальної суми доходів загального фонду бюджету ОТГ з дотаціями, але без урахування субвенцій з державного бюджету); співвідношення видатків на утримання апарату управління із фінансовими ресурсами ОТГ (співвідношення видатків на утримання апарату управління органів місцевого самоврядування із сумою доходів загального фонду без урахування трансфертів з державного бюджету, у відсотках); питома вага заробітної плати у видатках загального фонду бюджету ОТГ (відсоткова частка проведених із загального фонду бюджету видатків на заробітну плату з нарахуваннями до обсягу видатків загального фонду бюджету без урахування трансфертів, перерахованих з бюджету ОТГ до інших бюджетів); питома вага капітальних видатків у загальному обсязі видатків (частка капітальних видатків у сумарному обсязі видатків загального та спеціального фонду відповідного бюджету ОТГ); обсяг надходжень до бюджету ОТГ від сплати ПДФО на 1-го мешканця; обсяг надходжень до бюджету ОТГ від плати за землю на 1-го мешканця; обсяг надходжень до бюджету ОТГ від сплати єдиного податку на 1-го мешканця; обсяг надходжень до бюджету ОТГ від сплати акцизного податку на 1-го мешканця; обсяг надходжень до бюджету ОТГ від сплати податку на нерухоме майно на 1-го мешканця (табл.2).

Відслідковуємо цікаву тенденцію, група ОТГ з населенням понад 15 тис осіб має у своєму складі має лише 3 громади. Кожна наступна група у якій населення громад поступово зменшується має у своєму складі більшу кількість сформованих громад. Так для прикладу група з населенням від 10 до 15 тис осіб формується з 5 ОТГ, від 5 до 10 тис осіб - з 25 громад. Також зазначимо, що зростання чисельності населення спонукає до зростання суми власних доходів, отриманих ОТГ відповідної групи. Однак, цікавим $€$ факт, що зі зростанням населення ОТГ диференціація між найвищим та найнижчим показником суми доходів на 1 мешканця зменшується. Аналіз доходів загального фонду місцевих бюджетів ОТГ Волинської області свідчить про те, що найбільший дохід має Боратинська ОТГ. Найменший дохід має Велимченська ОТГ. В топ-5 лідируючих позицій за даним показником входить також Підгайцівська, Зарічанська, Липинська та Рівненська ОТГ. На такий стан речей впливає низка факторів: вікова структура працездатного населення, питома вага зайнятих і безробітних у загальній структурі населення ОТГ; ефективність адміністрування податків; оцінка збалансованості та стабільності податкової системи; динаміка розвитку економічного, культурного, освітнього та інших сфер ОТГ; показники платоспроможності, соціального та фінансового забезпечення населення; участь в грантах, проєктах і т.д, швидкість та ефективність місцевого самоврядування у прийняті рішень щодо проблем ОТГ. 
Таблиця 2

Показники бюджетної самодостатності ОТГ Волинської області у 2019 році

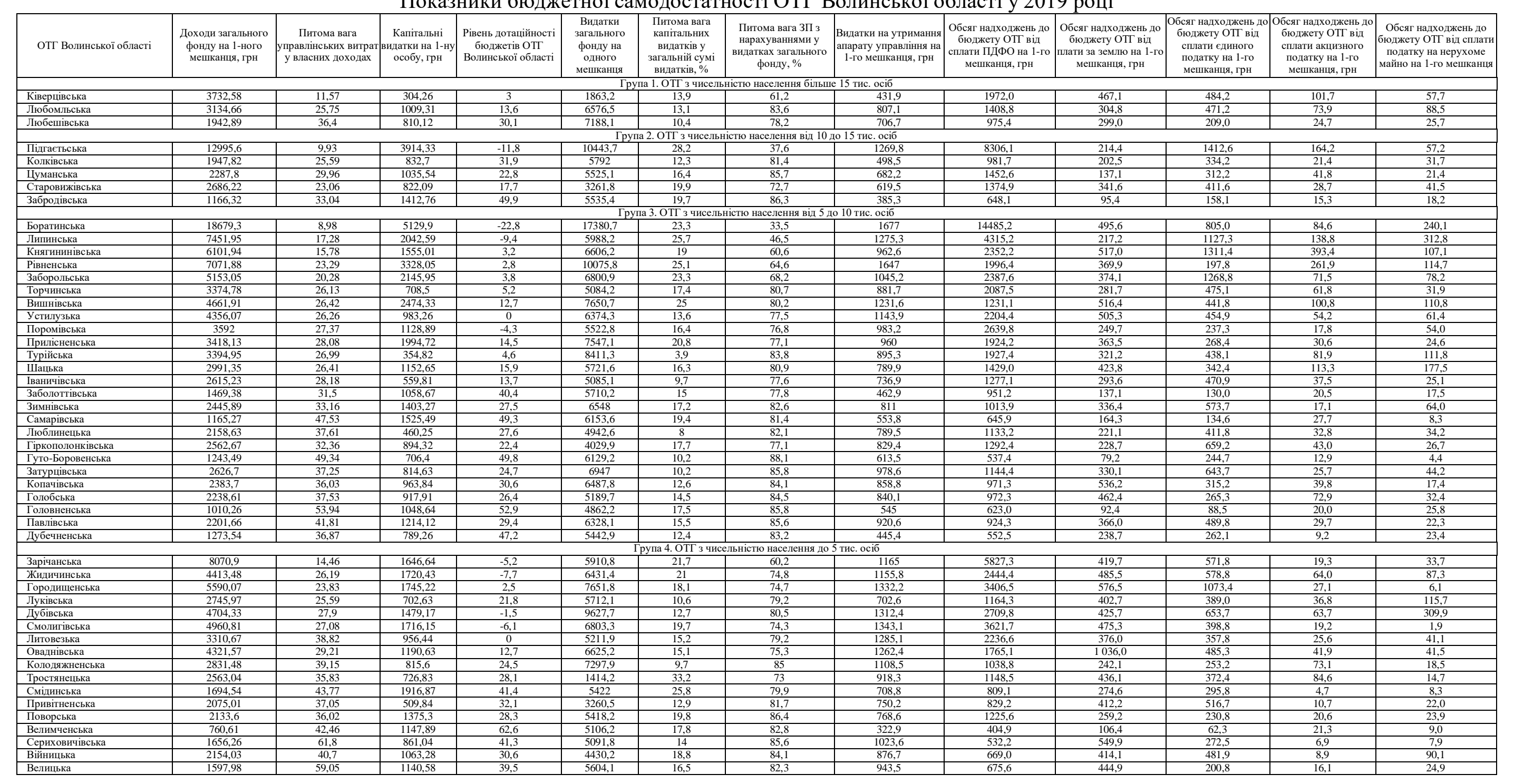


Розглянувши видатки загального фонду місцевих бюджетів ОТГ Волинської області, можна побачити, що Боратинська та Підгайцівська ОТГ залишається лідерами за даним показником. Наступних три ОТГ змінюються на Рівненську, Дубнівську і Турійську. Аутсайдером є Тростянецька ОТГ. Спостерігаючи за співвідношенням видатків над доходами, можна помітити, що у багатьох ОТГ видатки більші за доходи. На ці дані є ймовірний вплив таких факторів: не ефективний розподіл коштів; значна частка видатків витрачаються на одну або декілька найпроблемніших сфер ОТГ; значна частка видатків витрачається на утримання апарату державних службовців; нераціональність у використанні видатків; відсутність аналізу динаміки розвитку певних сфер ОТГ; не залучення додаткових коштів до бюджету; не передбачені витрати.

Як і раніше, переважна більшість наших територій (40 місцевих бюджетів ОТГ) є дотаційними. Загрозливими показниками характеризуються низка ОТГ: Велимчанська $62,6 \%$, Головненська - 52,9\%. Забродівська - 49,9 \%, Гуто-Боровеньська - 49,8\%, Самарівська - 49,3 \%. Ще дві громади Волинської області будуть бездотаційними (тобто, їх податкоспроможність близька до середньої по державі): Устилузька, Литовезьська. У групу до заможних ОТГ, які ділитимуться коштами з державою відійшли: Боратинська, Підгаєтьська, Липинська, Жидичинська, Смолигівська, Зарічанська, Поромівська. Найбільша питома вага видатків на утримання апарату управління у власних ресурсах ОТГ (без урахування трансфертів) припадає на бюджет Сереховичівської ОТГ - 61,8\%, найменша - на бюджет Боратинської ОТГ - 8,98\%. За оцінками експертів, при більшій фінансовій спроможності бюджету частка видатків на утримання апарату управління буде меншою. Тому, у бюджетах із більшим ресурсом витрати на апарат управління у відсотковому вираженні є меншими. Внаслідок цього, такі громади мають можливість спрямувати більше коштів на розвиток своїх територій. Крім Боратинської ОТГ, як найкращої за цим показником, сюди можна віднести ще Підгаєтьську, Ківерцівську та Зарічанську. Їх показник не перевищує $15 \%$.

Середній розмір капітальних видатків на 1-го мешканця (без урахування власних надходжень бюджетних установ) по 50 ОТГ області склав 1249,77 грн. Найбільше капітальних видатків у розрахунку на мешканця було проведено у Боратинській ОТГ 5129,9 грн, найменше з бюджету Ківерцівської ОТГ - 304,26 грн.

Транспарентність або відкритість бюджету та бюджетного процесу теж вважаємо елементом бюджетної ефективності, яка лежить у площині представлення інтересів різних верств населення, можливості впливу на органи влади, захищаючи свої громадянські права. «Якщо бути більш точним, то прозорість: дозволяє кожному громадянину розуміти мову і дані бюджету, а також бачити послуги, виконані за рахунок зібраних податків; дає можливість представникам влади керуватись громадською думкою при прийнятті остаточних бюджетних рішень (основні напрямки розподілу видатків); дозволяє відслідковувати якість бюджетних рішень на стадії прийняття та слідкувати за їх виконанням; підсилює довіру населення до місцевих органів влади, тому що розуміння дій представників влади $є$ передумовою громадської підтримки; сприяє поліпшенню соціальної політики і розподілу коштів бюджету» [3].

При цьому відкритість може бути досягнута у першу чергу через поінформованість населення. Для якісної оцінки бюджетної відкритості (табл. 3) нами запропоновані наступні показники: наявність окремої вкладки на сайті ОТГ фінанси/бюджет; оприлюдення рішень про місцевий бюджет на сайті ОТГ; оприлюднення паспортів бюджетних програм місцевого бюджету на сайті ОТГ; оприлюднення звітів паспортів бюджетних програм місцевого бюджету на сайті ОТГ; громадські бюджетні слухання (кількість за рік) та рівень відкритості місцевих рад (за результатами задоволення запитів). 
Таблиця 3

Показники бюджетної транспарентності ОТГ Волинської області у 2019 році

\begin{tabular}{|c|c|c|c|c|c|c|c|c|}
\hline \multirow{2}{*}{ ОТГ Волинської області } & \multirow{2}{*}{$\begin{array}{c}\text { Наявність окремої вктадки на сайті } \\
\text { ОТГ фінанси/бюджет (+/-) }\end{array}$} & \multirow{2}{*}{$\begin{array}{l}\text { Оприлюдення рішень про місцевий } \\
\text { бюжжет на сайті ОТГ }(+/) \text {. }\end{array}$} & \multirow{2}{*}{$\begin{array}{l}\text { Оприлюднення паспортів бюджетних } \\
\text { програм місцевого бюджжгу на сайті ОТГ }\end{array}$} & \multirow{2}{*}{$\begin{array}{l}\text { Оприлюднення звітів паспортів бюджетних } \\
\text { програм місцевого бюджету }\end{array}$} & \multirow{2}{*}{$\begin{array}{c}\text { Громадсскк бюожжетні слухання } \\
\text { (кільість за рік) }\end{array}$} & \multicolumn{3}{|c|}{ Розгляд запипів на інформапію } \\
\hline & & & & & & Подано & Задоволено & Рівень відкритості \\
\hline \multicolumn{9}{|c|}{ Група 1. ОТГ з чисельністю населення більше 15 тис. осіб } \\
\hline Ківерцівська & + & & - & & - & - & - & 0 \\
\hline Старовижівська & + & + & + & + & 1 & 8 & 8 & 1 \\
\hline Любомльська & + & - & - & - & - & - & - & 0 \\
\hline Любешівська & + & + & + & + & 1 & 311 & 311 & 1 \\
\hline \multicolumn{9}{|c|}{ Група 2. ОТГ з чисельністю населення від 10 до 15 тис. осіб } \\
\hline Підгастьська & + & + & - & - & - & - & - & 0 \\
\hline Колківська & + & + & + & + & - & - & - & 0 \\
\hline ЦЦуманська & + & - & - & - & - & - & - & 0 \\
\hline Старовижівська & + & + & + & + & 1 & 8 & 8 & 1 \\
\hline Забродівська & + & - & & - & - & - & - & 0 \\
\hline \multicolumn{9}{|c|}{ Група 3. ОТГ з чисельністю населення від 5 до 10 тис. осіб } \\
\hline Боратинська & + & + & + & + & - & - & - & 0 \\
\hline Липинська & + & - & - & - & - & - & - & 0 \\
\hline Княгининівська & + & - & - & - & - & - & - & 0 \\
\hline Рівненська & + & + & + & + & 3 & 12 & 11 & 0,917 \\
\hline Заборольсьька & $+\frac{1}{+}$ & + & $\frac{t}{-}$ & $\frac{t}{-}$ & $\frac{-}{-}$ & 12 & 11 & $\frac{0,117}{0}$ \\
\hline Торчинська & + & - & - & - & - & - & - & 0 \\
\hline Вишнівська & + & - & - & - & - & - & 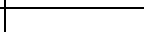 & 0 \\
\hline Устилузька & + & - & - & - & - & - & & 0 \\
\hline Поромівська & + & + & + & - & 2 & 3 & 3 & 1 \\
\hline Прилісненська & + & - & - & - & - & - & & 0 \\
\hline Турійська & + & + & - & - & 5 & 29 & 0 & 0 \\
\hline Шацька & + & + & + & $\begin{array}{lll}+ & & \end{array}$ & 1 & 1 & 1 & 1 \\
\hline Іваничівська & + & & & & & & & 0 \\
\hline Заболоттівська & + & & & & & & & 0 \\
\hline Зимнівська & + & & & & & & & 0 \\
\hline Самарівська & + & & & & & & & 0 \\
\hline Люболинецька & + & + & + & + & 3 & 1 & 1 & 1 \\
\hline Гіркополонківська & + & & & & & & & 0 \\
\hline Гуто-Боровенська & + & & & & & & & 0 \\
\hline 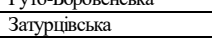 & $+\frac{1}{+}$ & & & & & & & 0 \\
\hline Копатіiсcкаa & + & & & & & & & 0 \\
\hline Голобсска & + & + & + & - & - & 10 & 10 & 1 \\
\hline Головненська & + & & & & & & & 0 \\
\hline Павлівська & + & + & + & + & 6 & - & - & 0 \\
\hline Дубечнненська & + & & & & & & & 0 \\
\hline \multicolumn{9}{|c|}{ Група 4. ОТГ з чисельністю населення до 5 тис. осіб } \\
\hline Зарічанська & + & & & & & & & \\
\hline Жидичинська & + & + & - & - & 1 & 7 & 7 & 1 \\
\hline Городищенська & + & + & + & - & - & 2 & 2 & 1 \\
\hline Луківська & + & & & & & & & 0 \\
\hline Дубівська & + & - & - & - & - & - & 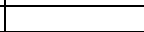 & 0 \\
\hline Смолигівська & + & - & - & - & - & - & & 0 \\
\hline Литовезька & + & - & - & - & - & - & & 0 \\
\hline Оваднівська & + & + & + & + & 8 & 14 & 12 & 0,857 \\
\hline Колоджжныненська & $+\frac{t}{+}$ & $+\frac{t}{+}$ & $\frac{t}{+}$ & $+\frac{t}{+}$ & $\frac{0}{2}$ & $\frac{14}{-}$ & $\frac{12}{-}$ & $\frac{0,0 / 1}{0}$ \\
\hline 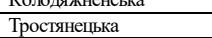 & $\frac{t}{+}$ & & & & & & & $\frac{0}{0}$ \\
\hline Смідинська & + & + & + & + & 1 & - & & 0 \\
\hline Привітненська & + & & & & & & & 0 \\
\hline Поворська & + & + & - & - & - & 7 & 7 & 1 \\
\hline Велимченська & + & & & & & & & 0 \\
\hline Сериховичівська & + & + & + & + & 1 & 12 & 12 & 1 \\
\hline Війницька & + & & & & & & & 0 \\
\hline Велишька & + & + & + & + & & & & 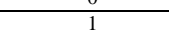 \\
\hline
\end{tabular}


Підсумовуючи зазначимо, що сфері транспарентності бюджетів ОТГ Волинської області притаманні вагомі проблеми, що підтверджується дослідженнями представленими у табл. 3. Їх вирішення потребує не лише забезпечення доступу до бюджетної інформації, але і формування організаційного механізму транспарентності бюджетного процесу на місцевому рівні, що вимагає формування дієвої системи інформування з питань створення та реалізації бюджету громади, нормативно-правової основи іiі функціонування та ефективних процедур і алгоритмів забезпечення відкритості бюджетів різного рівня. Виняткової уваги, на наш погляд, вимагає активізація громадянського суспільства, залучення громад до прийняття загальнозначущих рішень, покращення інституціонального клімату реалізації громадянських ініціатив, узгодження процесів висвітлення інформації на офіційних сайтах ОТГ, що дозволить поліпшити у перспективі показники транспарентності.

Групування ОТГ Волинської області за рівнем бюджетної ефективності (визначеного на базі розрахованого індексу бюджетної ефективності $\mathrm{I}_{\text {бе }}$ наведено у таблиці 4.

Таблиця 4

Групування ОТГ Волинської області за рівнем бюджетної ефективності

\begin{tabular}{|c|c|c|c|}
\hline $\begin{array}{c}\text { Значення } \\
\text { індексу I } \mathrm{I}_{6 . п}\end{array}$ & $\begin{array}{c}\text { Рівень } \\
\text { бюджетної } \\
\text { ефективності }\end{array}$ & $\begin{array}{c}\text { Якісна оцінка } \\
\text { використання } \\
\text { бюджетного потенціалу }\end{array}$ & ОТГ Волинської області \\
\hline $0,691 \leq \mathrm{I}_{\overline{ }} \leq 1,000$ & Високий & $\begin{array}{c}\text { Використовується } \\
\text { повно та результативно }\end{array}$ & $\begin{array}{l}\text { Боратинська, Підгаєтьська, Оваднівська, } \\
\text { Любешівська, Рівненська }\end{array}$ \\
\hline $0,407 \leq \mathrm{I}_{\overline{\sigma e}}<0,691$ & Середній & $\begin{array}{c}\text { Використовується } \\
\text { неповністю та } \\
\text { недостатньо ефективно }\end{array}$ & 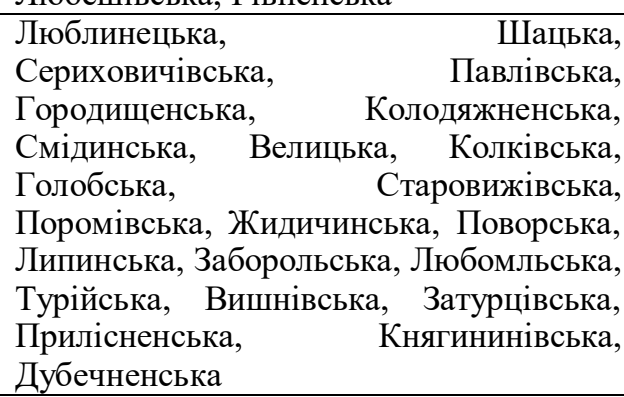 \\
\hline $0 \leq \mathrm{I}_{\overline{\sigma e}}<0,407$ & Низький & $\begin{array}{c}\text { Недостатньо } \\
\text { використовується }\end{array}$ & $\begin{array}{l}\text { Заболоттівська, Зимнівська, } \\
\text { Головненська, Копачівська, Війницька, } \\
\text { Гіркополонківська, Ківерцівська, } \\
\text { Зарічанська, Самарівська, Луківська, } \\
\text { Дубівська, Велимченська, Забродівська, } \\
\text { Іваничівська, Цуманська, Торчинська, } \\
\text { Устилузька, Гуос-Боровенська, } \\
\text { Смолигівська, Литовезька, } \\
\text { Привітненська, Тростянецька }\end{array}$ \\
\hline
\end{tabular}

Враховуючи результати вище наведеного типологічного групування територій зауважимо, що високим рівнем бюджетної ефективності відзначаються Боратинська, Підгаєтьська, Оваднівська, Любешівська, Рівненська ОТГ.

Низький рівень бюджетного потенціалу притаманний 22 з 50 ОТГ. Зокрема це Заболоттівська, Зимнівська, Головненська, Копачівська, Війницька, Гіркополонківська, Ківерцівська, Зарічанська, Самарівська, Луківська, Дубівська, Велимченська, Забродівська, Іваничівська, Цуманська, Торчинська, Устилузька, Гуто-Боровенська, Смолигівська, Литовезька, Привітненська, Тростянецькаоб'єднані територіальні громади.

Висновки. Цілком очевидним лишається факт, що розвиток ОТГ безпосередньо залежить від рівня бюджетної ефективності, від того наскільки результуючий, самодостатній та відкритий регіон у формуванні достатнього фінансового забезпечення, необхідного для реалізації ним делегованих державою функцій. У зв'язку з цим особливої актуальності набуває, розробка механізму підвищення бюджетної 
ефективності ОТГ загалом та обгрунтування раціональної структури фінансових ресурсів зокрема.

\section{Список бібліографічного опису}

1.Саймон Г.А. Адміністративна поведінка. - К. : АртЕк, 2001. - 231 с.

2.Причини невиконання бюджетних програм. - [Електронний ресурc]. - Режим доступу: https:/feao.org.ua/wpcontent/uploads/2019/01/reasons.pdfФахрутдинова Е. В.

3.Маркович Г. Публічність та прозорість бюджетного процесу - ознака демократичного розвитку країни. [Електронний ресурс] - Режим доступу: https://decentralization.gov.ua/news/4992.

\section{References}

1.Simon G. (2001). Administrative behavior. - K.: ArtEk, 2001. - 231 p.

2.Reasons of non-fulfillment of the budgetary programs. URL:

https://feao.org.ua/wp-content/uploads/2019/01/reasons.pdfФахрутдинова E. B.

3.Markovich G. Publicity and transparency of budgetary process are a sign of democratic development of country. URL: https://decentralization.gov.ua/news/4992.

Дата подання публікації 20.12.2020 p.

\section{УДК 330.341.1}

Таран С.Ф.,

здобувач кафедри підприємництва, торгівлі та біржової діяльності graduate student of the Department of Entrepreneurship, Trade and Exchange Activities, https://orcid.org/ orcid.org/0000-0002-6119-5871

\section{ФОРМУВАННЯ ОРГАНІЗАЦИЙНО-ЕКОНОМІЧНОГО МЕХАНІЗМУ РОЗВИТКУ ІННОВАЦІЙНОГО ПІДПРИЕМНИЦТВА РЕГІОНУ}

\section{Луцьький національний технічний університет}

Стаття присвячена теоретичним засадам формування організаційно-економічного механізму розвитку інноваційного підприємництва на рівні регіону. Проаналізовано та визначено основні фактори впливу на стан та розвиток інноваційного підприємництва в регіоні, до яких віднесено: посилення деструктивних впливів на стан та розвиток регіону; нестача кваліфікованих кадрів, задіяних в розвитку інноваційного підприємництва; недосконалість комунікацій між наукою, бізнесом та владою; відсутність єдиного стратегічного бачення розвитку інноваційного підприємництва регіонів держави тощо.

Визначено структурні елементи досліджуваного механізму, до яких віднесено організаційні, інституційні та економічні складові, що формують комплекс важелів управління процесом розвитку інноваційного підприємництва регіону. Систематизовано основні типи стейкхолдерів розвитку інноваційного підприємництва регіону, до яких віднесено органи влади, підприємницькі суб'єкти регіону, інвестори, громадськість, міжнародні стейкхолдери, інститути знань.

3 метою більш чіткого визначення переліку інструментів досліджуваного механізму, які відповідають його конкретним стратегічним цілям, сформовано та деталізовано пріоритети регулювання розвитку інноваційного підприємництва регіону. До таких приорітетів віднесено: формування та реалізацію конкурентоспроможних регіональних інноваційних продуктів та послуг; підвищення рівня якості інституційної інфраструктури інноваційного підприємництва регіону; удосконалення інформаційного забезпечення інноваційного підприємництва регіону; організація системи якісної підготовки кваліфікованих фахівців для сфери інноваційного підприємництва; системна детінізація діяльності суб'єктів підприємництва регіону.

Доведено, що регулювання розвитком інноваційного підприємництва регіону здійснюється шляхом визначення і підтримки пріоритетних напрямів як державного та галузевого, так і регіонального та місцевого рівня. Більшість регіонів, шляхом формування і реалізації регіональних стратегій та програм самостійно здійснюють підтримку та розвиток інноваційного підприємництва, виділяють кошти з власних бюджетів на провадження науково-дослідницької діяльності та на впровадження інновацій в регіоні. Крім того, регіони захищають права та інтереси суб'єктів інноваційної діяльності, забезпечують фінансову підтримку виконання інноваційних проектів, стимулюють комерційні банки та інші фінансово-кредитні установи, що 